\title{
Zmiany na europejskim rynku dostaw taboru samochodowego do przewozów towarowych
}

Jarosław Brach*

\section{Wstęp}

Obecnie zachodzą dość poważne, wręcz rewolucyjne zmiany zasad funkcjonowania rynku pojazdów użytkowych. Nowe zasady są wprowadzane przede wszystkim w krajach najbardziej rozwiniętych, czyli w krajach Unii Europejskiej oraz Ameryki Północnej. Są one rezultatem zmierzania tego rynku do postępu i rozwoju, będących następstwem czwartej rewolucji przemysłowej, tzw. Rewolucji 4.0, prowadzącej do powstawania tzw. Gospodarki 4.0, a w jej ramach: Przemysłu 4.0 (Trapp 2017; The Future is Smart...; Kagermann i in. 2013; Löffler, Tschiesner 2013; Baur, Wee 2015; MacDugall 2014; Ruoff 2016, s. 74-76) oraz powiązanych z nim m.in. Mediów 4.0 (Kupczyk 2016, s. 52-64), Logistyki 4.0 (Weiss 2016, s. 195, Bernsmann, i in. 2016, s. 16-31) i Transportu 4.0 (Brach 2017). Ten ostatni ściśle wiąże się zaś z Pojazdem Użytkowym 4.0 oraz Mobilnością 4.0 (Brach 2017).

Celem tego artykułu jest przedstawienie obecnych zmian na europejskim rynku dostaw taboru samochodowego do przewozów towarowych jako następstwa przechodzenia gospodarki na poziom określany jako 4.0. Analizę przeprowadzono głównie od strony podażowej, czyli z punktu widzenia producentów tego taboru. Zwrócono uwagę m.in. na to, jak te przekształcenia wpływają na omawiany rynek, a także na związki pomiędzy tworzącymi go podmiotami oraz powstawanie nowych relacji, zjawisk i zależności biznesowych. W tym kontekście przybliżono m.in. problematykę zmiany roli dostawcy i użytkownika taboru co do zakresu pełnionych przez nich funkcji i realizowanych zadań. Nie poddano rozważaniom zmian po stronie odbiorców - wymagają one dokładnego omówienia w odrębnym studium przypadku.

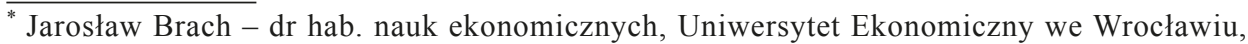
Wydział Nauk Ekonomicznych, Katedra Międzynarodowych Stosunków Gospodarczych, jaroslaw.brach@ue.wroc.pl
} 
Artykuł ten powstał przede wszystkim na podstawie analizy najnowszych zagranicznych opracowań dotyczących tego rynku oraz zachodzących na nim procesów. Opracowania te pochodzą z renomowanych instytutów badawczych oraz od dostawców taboru samochodowego i kluczowych komponentów do niego. Część tych ostatnich źródeł jest niejawna. Mimo tego informacje przez nie dostarczone zostały wykorzystane, gdyż pozwalają na wysnucie pewnych istotnych wniosków, które nie byłoby możliwe, gdyby autor korzystał jedynie z oficjalnych źródeł. Artykuł zawiera też wiele własnych wniosków i spostrzeżeń autora, który od wielu lat zajmuje się badaniem tego rynku, w tym zachodzących na nim zjawisk oraz jego transformacji.

Jednocześnie autor pragnie zwrócić uwagę na dwie istotne powiązane kwestie. Po pierwsze, przybliżane $\mathrm{w}$ tym artykule procesy formują się i zachodzą teraz, na naszych oczach. Nie są one zjawiskiem nowym - stanowią wynik zmieniającego się podziału pracy i postępującej specjalizacji - ale obecnie doszło do ich znacznego zdynamizowania, w związku z czym nabierają one kompletnie innego wymiaru, wymiaru 4.0. W efekcie trudno teraz przewidywać ich ostateczny kształt, charakter, natężenie i kierunek. Pewne opracowania przekazane przez producentów zawierają treści całkowicie lub częściowo niejawne właśnie dlatego, że bezpośrednio odnoszą się one do strategii realizowanej obecnie przez te podmioty $\mathrm{i}$ - w tym kontekście - do podejmowanych przez nie działań. Tym samym dotyczą spraw niezwykle „wrażliwych” dla każdego przedsiębiorcy i nie mogą być dostępne dla osób nieuprawnionych. Dlatego też nie ma wielu fachowych materiałów na ten temat. Niniejszy artykuł stanowi takie opracowanie i jest tym samym jedną z pierwszych dogłębniejszych jawnych analiz poświęconych temu zagadnieniu, opublikowanych w naszym kraju.

\section{Podstawowe założenia}

Zmiany zachodzące obecnie na europejskim rynku pojazdów użytkowych mają głównie wymiar:

1) techniczny i technologiczny - w zakresie stosowanych technologii, zwłaszcza w obszarze postępującego ucyfrowienia - zdolności do generowania, obróbki, przechowywania, analizy i przesyłania znacznych ilości danych w czasie rzeczywistym lub niezwykle szybko;

2) organizacyjny - w zakresie zmian struktur organizacyjnych we włączonych podmiotach związanych ze zmianą sposobu:

- dla dostawców - dojścia do klienta i jego obsługi;

- dla klientów, przewoźników - dostosowania własnej organizacji z etapu posiadania do poziomu dysponowania i użytkowania;

- dla zleceniodawców - potrzeby jeszcze ściślejszej wspólpracy z przewoźnikami; 
3) mentalny - wynikający z konieczności zmiany postrzegania rynku jako takiego oraz poszczególnych jego uczestników przez wszystkie zaangażowane strony.

\section{Zasadnicze tendencje}

\section{Mobilność 4.0 i Transport 4.0}

Pod względem podstawowych procesów zachodzące obecnie zmiany wyrażają się stale wzrastającymi m.in. sieciowością, autonomizacją i proekologicznością. Zjawiska te wprost wynikają z Mobilności 4.0 oraz Transportu 4.0. Mobilność 4.0 (Jeschke i in. 2014) oznacza bowiem ruchliwość zwiększoną i bardziej efektywną w układach: czasowym, organizacyjnym i kosztowym. Wyraża się ona przez zdolność do sprawnego i elastycznego przemieszczania oraz bazuje na trzech zasadniczych elementach, którymi są: postępujące zelektryfikowanie, sieciowość i autonomizacja. Transport 4.0 (Brach 2017) to stanowiący fundament Mobilności 4.0 w coraz większym stopniu autonomiczny proces przemieszania wraz z wszelkimi czynnościami mu towarzyszącymi, funkcjonujący w środowisku usieciowionym i pełnym informacji. Musi łączyć trzy zasadnicze składowe:

1) „inteligencję”, „spryt” - łatwość umiejętnego uczenia się i samoeliminacji ewentualnych błędów, wad i niedociągnięć;

2) szybkość - zdolność do niezwłocznej reakcji w przypadku zmian wymagań w relacji rynek - potrzeba - działanie;

3) prostotę - poprawione adaptacyjność, konsumowalność oraz elastyczność, co oznacza zdolność do działania optymalnego w odniesieniu do ewaluujących potrzeb i wymagań.

Transport 4.0 opiera się też na stałym doskonaleniu i jest ukierunkowany na permanentne, elastyczne optymalizowanie ogółu dokonywanych operacji w układach czasowym, organizacyjnym i kosztowym. Procesy te zachodzą w ramach realizacji zadań w logistycznych sieciach tworzenia wartości wykreowanych w obsłudze ucyfrowionego, sieciowego Przemysłu 4.0. Tym samym Transport 4.0, wsparty Mobilnością 4.0, jest jedną z podstaw funkcjonowania Logistyki 4.0 działającej na rzecz Przemysłu 4.0 (Jeschke 2016; Hülsmann 2015; Heinrichmeyer 2017; Baur, Wee 2015).

\section{Nowe modele biznesowe}

Wymienione zmiany prowadzą do dualizacji i hybrydyzacji dotychczasowych modeli biznesowych. Oznacza to m.in. konieczność jeszcze ściślejszej współpracy wszystkich powiązanych podmiotów i w tym kontekście połączenia w jeden produkt rynkowy, produkt rynkowo zintegrowany, składowych będących dotąd 
oddzielnymi bytami. Będzie to zatem zarówno dla dostawców, jak i użytkowników rynek produktów łączonych. Dla użytkowników, bo otrzymają jeden złożony produkt finalny dostarczany im przez jedno źródło, jednego dostawcę. Dla dostawców, gdyż dla finalnego nabywcy ostateczny produkt będzie dostępny jako jedna, zintegrowana i kompletna całość, chociaż będzie się na nią składać wiele subproduktów pochodzących od szeregu podmiotów współdziałających ze sobą właśnie w celu przedstawienia tej jednolitej całości. Wyróżnikami tego produktu będą:

1) elastyczność i elastyczne różnicowanie, określane także mianem melanżyzacyjnej hybrydyzacji;

2) eklektyzm - otwartość na nowe składowe;

3) silniejsza, stale pogłębiana indywidualizacja pod kątem jeszcze lepszego zaspokajania nawet specyficznych, w tym wybitnie niszowych, potrzeb odbiorców;

4) holizm - bazowanie na podejściu, że zarówno własna organizacja, jak i otoczenie tworzą połączone systemy całościowe, podlegające prawidłowościom niemożliwym do wywnioskowania jedynie na podstawie wiedzy, nawet bardzo dogłębnej, dotyczącej zasad rządzących każdym z tych składników z osobna; w efekcie suma składowych nie tworzy jednolitej całości, ponieważ całość oddziałuje równocześnie na składowe w sposób nieraz niezwykle unikatowy.

Zmiany te są możliwe do wprowadzenia jedynie wtedy, kiedy zainteresowane strony, głównie dostawcy pojazdów i komponentów podlegających zużyciu, dysponują dokładnymi danymi na temat sposobu eksploatacji określonych rodzajów taboru w określonych warunkach i ściśle powiązanej z tymi elementami wielkości oraz struktury kosztów. W uzyskaniu tych danych - nawet w czasie rzeczywistym - kluczową rolę odgrywa jeden z podstawowych elementów Rewolucji 4.0, czyli wspomniana sieciowość.

W układzie podmiotowym i obszarowym zaznaczone procesy dotyczą:

1) sposobu dojścia do klienta przez dostawców pojazdów użytkowych oraz współpracujących z nimi dostawców usług powiązanych, skojarzonych;

2) zmiany relacji i zasad współpracy w układzie dostawca taboru - jego użytkownik;

3) zmiany zasad prowadzenia biznesu przez samych przewoźników.

W pierwszym przypadku kwestia wiąże się ze zmianą zawartości produktu finalnego. Już teraz sprzedający coraz częściej proponują nie same pojazdy wraz z usługami towarzyszącymi, jak obowiązkowa gwarancja i nierzadko gwarancja przedłużona, wsparte elementami finansowymi (kredyt, leasing fabryczny, ewentualne ubezpieczenia) i innymi, jak buy-back (gwarancja odkupu taboru po określonym czasie jego eksploatacji), ale stają się dostawcami kompleksowego produktu - tzw. kompletnego zintegrowanego rozwiązania transportowego. Należy zatem wskazać na zmianę generalnej tendencji na rynku w zakresie postrzegania 
ciężarówki, tzn. przechodzenie z poziomu widzenia i posiadania jej jako dobra do poziomu dysponowania i korzystania z niej jako narzędzia (DAF 2017). W przeszłości - w tzw. modelu historycznym - producent głównie dostarczał właśnie ciężarówkę i w odpowiadał za jej koncepcję, rozwój, wytwarzanie oraz dystrybucję i marketing. Obecnie dostarcza nie tylko samą ciężarówkę, ale też ściśle powiązane z nią serwis i finansowanie. Doprowadziło to do powstania modelu rynkowego określanego jako ciężarówka oraz serwis i finansowanie. Wytwórca dodatkowo odpowiada zatem za finansowanie, serwis, ubezpieczenia i szkolenia. Te ostatnie zazwyczaj z zasad bezpiecznej jazdy oraz efektywnej w układach czasowym, organizacyjnym i kosztowym. W przyszłości wystąpi jako dostawca tzw. kompletnego rozwiązania transportowego, oprócz ciężarówki oraz modułu serwisu i finansowania zawierającego zestaw usług i produktów dodatkowych, nieraz dotąd nieistniejących lub wciąż nieskomercjalizowanych. Obecnie do usług tych zaliczamy: planowanie zadań i tras, zarządzanie flotą i cyklem życia, indywidualne portfolio - silne zindywidualizowanie oferty i podejścia, oznaczające jeszcze lepsze niż dzisiaj dopasowywanie oferty czy produktu do specyficznych wymagań konkretnego nabywcy, oraz branding, czyli budowanie świadomości marki. W większości są to zatem usługi związane nie tylko ze sferą samego przewozu, ale z sieciowo programowaną i wykonywaną obsługą logistyczno-transportową. Są tu bowiem silnie akcentowane czynności ukierunkowane na poprawę efektywności w powiązaniu z lepszym spożytkowaniem wszelkich dostępnych zasobów. Dlatego ze swojej strony dostawcy proponują tzw. kompletny pakiet wsparcia, którego składowe to (Continental 2017):

1) Jeden osobisty, profesjonalny partner do kontaktów. Chodzi o dostosowane do indywidualnych potrzeb modele biznesowe oraz rekomendacje produktów, co przejawia się znacznym zindywidualizowaniem ofert w zakresie ceny i warunków dostawy, w tym składowych okołoproduktowych. Ogólnie rzecz biorąc, dzisiaj zindywidualizowanie, czyli zindywidualizowane podejście, cechuje praktycznie całą ofertę flotową.

2) Wysokiej jakości produkty umożliwiające osiągnięcie najniższych całkowitych kosztów eksploatacji, przekładających się na najniższe możliwe do uzyskania w danych warunkach całkowite koszty posiadania i dysponowania (total costs of ownership - TCO). W skład tego modułu wchodzą ogólnoeuropejskie usługi assistance dostępne w wielu krajach przez 365 dni w roku, 7 dni w tygodniu i 24 godziny na dobę, uzupełnione i wsparte pełną obsługą w języku lokalnym.

3) Konkurencyjna i przejrzysta oferta - dostępność ogólnoeuropejskiej sieci serwisowej oraz ujednolicona struktura cenowa, co ma wyjątkowo duże znaczenie w przypadku przewozów w ruchu międzynarodowym.

4) Profesjonalne usługi zarządzania flotą i przejrzyste raporty. Pozwalają one na przeprowadzanie regularnych wielopłaszczyznowych analiz biznesowych oraz uzyskiwanie odpowiedniego doradztwa. 
Kluczowa jest w takim razie zmiana mentalna, ponieważ kompletne rozwiązanie transportowe to zespół powiązanych subproduktów skojarzonych, mających zabezpieczyć wszelkie potrzeby przewoźnika w wyniku dostarczenia mu narzędzi do pracy, by mógł wykonywać swoje zadania w sposób przynajmniej suboptymalny. Dlatego wymaga od przewoźnika zmiany sposobu postrzegania przez niego rynku. Tym bardziej że oprócz samego pojazdu produkt ten zawiera zintegrowane $\mathrm{z}$ nim:

1) finansowanie i ubezpieczenia;

2) pełne wsparcie - pełną obsługę przeglądowo-naprawczą w określonym czasie i na określonych warunkach w ramach kontraktów serwisowych;

3) gwarancję mobilności, czyli zapewnienie przewoźnikom tego, że eksploatowane przez nich pojazdy będą stale dostępne do wykonywania zadań, a ewentualne straty czasowe, spowodowane przeglądami i naprawami, zostaną zdecydowanie zredukowane; generalnie chodzi o tzw. obsługę predykcyjną - serwisowanie zapobiegawcze mające na celu uniknięcie nieprzewidzianych awarii.

W modelu tym zasadnicze zmiany dotyczą więc dwóch powiązanych ze sobą czynników. Po pierwsze, wskutek zawarcia umów na kontrakty obsługowo-naprawcze z punktu widzenia przewoźnika na znaczeniu, poza określonymi przypadkami, traci tradycyjnie pojęta gwarancja. $Z$ definicji jest ona przynajmniej częściowo wpisana w kontrakty, tzn. kontrakty te zawierają pewne czynności i przypadki dotychczas objęte klasyczną gwarancją. W efekcie, jeśli przez zadany okres to dostawca, producent zapewnia pełną mobilność taboru przekazanego przewoźnikom do eksploatacji, to on tę prawnie wymaganą gwarancję w określonym zakresie wpisuje w kontrakty i w ich ramach odpowiada za skuteczną likwidację niesprawności. Tym samym - zazwyczaj poprzez swoje różne filie albo podmioty ze sobą powiązane - producent sam sobie udziela gwarancji, udziela jej powiązana spółka sprzedażowa powiązanej spółce finansującej ten zakup, a następnie kierującej tabor do wynajmu. Wobec tego koszty likwidacji awarii są zawarte w kontrakcie i przewoźnik i tak uiszcza określoną wcześniej opłatę, niezależnie od tego, czy zepsuta część podlegałaby wymianie bądź naprawie na podstawie samej gwarancji, czy na podstawie rodzaju zawartego kontraktu serwisowego. W rezultacie przewoźnika kompletnie nie interesuje to, czy dostawca określone awarie usunął w ramach gwarancji, czy w ramach pakietu obsługi danego typu kontraktu serwisowego. Dostawca ma bowiem te awarie skutecznie usunąć na swój koszt. Tym samym, by móc zachować konkurencyjność, musi dysponować bardzo aktualnymi i precyzyjnymi danymi o realnych kosztach użytkowania określonego rodzaju taboru w określonych warunkach.

Po drugie, w ofercie dla przewoźników następuje przejście z poziomu posiadania do poziomu dysponowania przez nich środkami transportu. W takim układzie ponoszą ustalone opłaty za dostęp na określony czas do określonych środków 
o określonej specyfikacji. Płacą w takim razie za dostęp do taboru i za możliwość jego bezproblemowego użytkowania, czyli za eksploatację wyrażoną poprzez mobilność, a nie za bycie właścicielem eksploatowanych pojazdów. W związku z tym zjawisko to określa się mianem opłaty za dostęp do mobilności. W efekcie następuje odejście od tradycyjnego podejścia, w którym przewoźnik wchodził w posiadanie pojazdu na własność, kupując go za gotówkę, na kredyt bądź w leasingu. Obecnie i w przyszłości będzie on płacił za dostęp do gwarantowanej mobilności pojazdów formalnie należących do ich dostawców (producentów, pośredników) albo instytucji finansujących, jak towarzystwa leasingowe lub banki. Trzeba przy tym podkreślić, że dzisiaj sami producenci dysponują takimi podmiotami, będąc właścicielami banków lub organizacji finansujących bądź współpracując z takimi dostawcami zewnętrznymi. W ogólnym rozrachunku w tym rozwiązaniu pojazdy $\mathrm{i}$ tak będą więc formalną własnością instytucji finansującej. A to, czy ta instytucja jest powiązana z producentem, czy nie, nie jest istotne. Ważne wydaje się jedynie to, że pojazd będzie wynajmowany, a nie nabywany. Umowa ta w sensie prawnym może być zbliżona do obecnej umowy najmu albo może być nieco innym typem umowy, np. łączącym składowe leasingu i najmu. Kwestie te zapewne wkrótce zostaną doprecyzowane przez samych zainteresowanych.

Docelowo dzisiejsze opłaty leasingowe/kredytowe oraz kontrakt serwisowy zastąpi jedna opłata całościowa - zintegrowana opłata za mobilność. Obejmie ona, jako integralne składowe, ratę spłaty samego pojazdu oraz ratę opłaty eksploatacyjnej za pozycje dawniej ujęte w kontrakcie serwisowym, a w tym modelu zapewne funkcjonujące jako opłata za wsparcie serwisowo-przeglądowo-naprawcze. Rata opłaty za pojazd będzie się składać z dwóch podstawowych elementów: raty za dostępność do finansowania wynajmu mobilności oraz raty uwzględniającej spadek wartości pojazdu wskutek jego deprecjacji fizycznej, czyli postępującego zużycia eksploatacyjnego. Opłaty te będą zbieżne z płaconymi obecnie w przypadku leasingu dwoma ratami - kapitałową i odsetkową. Rata kapitałowa będzie dotyczyć spadku wartości pojazdu w czasie wskutek jego zużycia i starzenia się. Rata za dostępność do finansowania wynajmu mobilności będzie zaś klasyczną ratą odsetkową za dostęp do finansowania. A opłata za wsparcie serwisowo-przeglądowo-naprawcze będzie taka sama, jak obecna opłata za kontrakty serwisowe. Zależeć będzie zatem od ilości wyszczególnionych w kontrakcie pozycji, tzn. rodzaju udzielanego wsparcia. Ponadto trzeba wskazać, że w opłatę tę zostaną włączone koszty komponentów i materiałów podlegających normalnemu zużyciu eksploatacyjnemu, np. koszty ogumienia. Co więcej, ogumienie to będzie oczujnikowane - usieciowione i również udostępniane przewoźnikowi na zasadzie opłaty za dostęp do mobilności. Opłata ta będzie wchodzić w skład jednej ogólnej opłaty za dostęp do mobilności ponoszonej przez przewoźnika.

Przy tym, w celu większego uelastycznienia oraz zindywidualizowania, wysokość zazwyczaj comiesięcznej raty, uwzględniającej deprecjację, tj. spadek wartości fizycznej na skutek zużycia, oraz opłatę za wsparcie serwisowo- 
-przeglądowo-naprawcze, w pewnym zakresie będzie zależeć od uzyskiwanego przebiegu. Jeśli będzie mniejszy niż założono, wysokość tej opłaty spadnie, z kolei gdy będzie większy, proporcjonalnie wzrośnie. Do tego w sytuacji, gdy przez pewien okres pojazd nie będzie wcale użytkowany - będzie stał ze względu na brak zleceń - pojawi się opcja zawieszenia ponoszenia znacznej części tej opłaty. Tzn. przez pewien czas przewoźnik będzie mógł płacić jedynie raty odsetkowe za dostęp do mobilności. Wszystko to ma mu pomóc w prowadzeniu biznesu. Wychodzi się tu mianowicie ze słusznego założenia, że niepracujący pojazd nie zużywa się fizycznie i nie generuje przychodów. Wobec tego, ponieważ i tak obciąża przewoźnika pewnymi płatnościami stałymi z racji dysponowania nim, jak spłata odsetek za dostęp do mobilności, nie powinien stanowić dodatkowego pokaźnego źródła kosztów przy braku jakiegokolwiek pokrycia w notowanych przychodach.

Ciekawym produktem, już obecnym na polskim rynku, a wpisującym się $\mathrm{w}$ tę tendencję, jest proponowana od przełomu 2016 i 2017 roku przez Idea Bank tzw. fintechowa usługa Happy Miles (Idea Bank). Wykorzystuje ona technologię GPR i GPRS, a zebrane w ten sposób dane służą do wyliczenia rat. Oznacza to, że koszt leasingu, a w przyszłości też wynajmu długoterminowego, ma zależeć od tego, ile kilometrów klient przejedzie. To pierwsze tego typu rozwiązanie na świecie, w którym miesięczna rata leasingu wprost zależy od liczby kilometrów faktycznie pokonywanych przez leasingowany pojazd. Wysokość miesięcznej raty leasingowej kształtuje się więc na podstawie notowanego realnego przebiegu. Dodatkowo do usługi dołączono bogaty pakiet rozwiązań technologicznych, umożliwiających przedsiębiorcy uzyskanie kompleksowego obrazu wszystkich aspektów dotyczących floty samochodowej w jego firmie. Wśród tych rozwiązań znalazły się moduły zarządzania flotą i ekonomicznej jazdy, tzw. eco-drivingu.

Moduł zarządzania flotą to przyjazna oraz intuicyjna w obsłudze aplikacja mająca pomóc przewoźnikowi w bieżącym zarządzaniu pojazdami w jego firmie, m.in. jeśli chodzi o: zużycie paliwa, trasy przejazdu, ubezpieczenia, przeglądy techniczne i wiele innymi aspektów codziennej aktywności floty. Nadzorowane tu obszary to: gospodarka paliwowa, raporty drogowe, zarządzanie kierowca$\mathrm{mi}$, tachograf oraz zarządzanie przedsiębiorstwem. $\mathrm{Z}$ aplikacji tej, działającej na wszystkich systemach operacyjnych, można korzystać w każdej chwili, logując się na swoje konto w internecie bądź używając wersji mobilnej. Natomiast moduł EcoDriving służy temu, by w aplikacji Happy Miles we wszystkich pojazdach floty kontrolować zużycie paliwa, styl jazdy kierowców oraz stosowanie się do zasad eco-drivingu. W efekcie przewoźnik może zaoszczędzić na paliwie i amortyzacji taboru. Ponadto aplikacja pozwala na wystawianie ocen kierowcom, co poprawi jakość świadczonej przez nich pracy, a system rywalizacji służy jako dobre narzędzie do motywowania pracowników. 


\section{Następstwa zmian}

Elementy te wpłyną oczywiście na relacje między dostawcą taboru a jego użytkownikami. W relacjach tych pojawią się dwa podstawowe elementy, które są dostępne już dzisiaj, ale zapewne w nieodległej przyszłości stworzą jeden produkt:

1) usieciowione pojazdy bez możliwości rezygnacji z opcji usieciowienia;

2) opłata za dysponowanie, tj. za mobilność, a nie za posiadanie na własność.

W efekcie wzrosną kontrola przewoźnika i jego działań oraz stopień przywiązania przewoźnika do danego dostawcy. Kontrola wyniknie z faktu, że eksploatowany w środowisku sieciowym pojazd będzie (samoistnie) generował znaczne ilości danych na temat m.in. stanu swoich poszczególnych komponentów i zespołów, pozycji, trasy i jej przebiegu, ładunku (wykorzystania ładowności) czy sposobu i rodzaju eksploatacji. Dane te dotyczą więc wszystkiego, co wiąże się z tym pojazdem i co się z nim w określonym momencie dzieje. Dane te teoretycznie będą przechowywane i administrowane przez uprawnione jednostki u nadzorców systemów sieciowych. Niemniej niezmiernie łatwy dostęp do nich uzyskają m.in. uprawnione państwowe jednostki nadzoru i kontroli, jak policja albo inspekcja drogowa. A z tego część przewoźników może nie być zadowolona. Trudno mianowicie będzie im ukryć „,szarość” niektórych operacji, np. przeładowywanie.

Temu wzrostowi kontroli towarzyszyć będzie wzrost stopnia przywiązania przewoźników do dostawców taboru. W dotychczasowym modelu kształtowania stosunków między nimi, w przypadku zakupów za gotówkę, w kredycie albo leasingu, to przywiązanie trwało zazwyczaj tak długo, jak długo obowiązywała standardowa gwarancja, ewentualnie gwarancja przedłużona, czyli rok, maksymalnie - przy gwarancji przedłużonej - dwa, trzy lata. Potem przewoźnik mógł z danym pojazdem robić, co chciał. Mógł go dalej przeglądać oraz naprawiać $\mathrm{w}$ autoryzowanych warsztatach, przez co przedłużał swój kontakt z dostawcą. Równie dobrze mógł jednak takich przeglądów i napraw dokonywać w punktach nieautoryzowanych czy we własnym zakresie. Kwestiami wtórnymi były w tym przypadku jakość napraw i przeglądów oraz spadek wartości rezydualnej tak serwisowanego taboru.

Sytuację w tym zakresie zmieniły dopiero kontrakty serwisowe oraz umowy najmu średnio- i długoterminowego, przeciętnie trwające od dwóch do pięciu lat. W ich przypadku przewoźnik jest już zmuszony do korzystania wyłącznie ze wsparcia udzielanego przez autoryzowane punkty przez cały okres użytkowania pojazdów. W dodatku musi korzystać z tego wsparcia w ściśle określonym czasie, by nie narazić się na ewentualne kary. Analogiczna sytuacja wystąpi w przypadku umów dostępu do mobilności, tzn. przez cały okres ich obowiązywania przewoźnik będzie zmuszony do korzystania tylko i wyłącznie z usług punktów autoryzowanych. 
Obecnie działania dotyczące takich pojazdów po upływie określonego w umowie czasu dostępu pozostają kwestią otwartą. Wyjścia są trzy:

1) Wykup pojazdu lub wzięcie go w leasing, w tym fabryczny, przez użytkujący go dotąd podmiot bądź inny.

2) Zwrot do właściciela, czyli dostawcy taboru. W zamian przewoźnik może uzyskać dostęp do mobilności nowego taboru u tego dostawcy lub skorzystać z usług innego, zdaniem przewoźnika proponującego mu generalnie lepsze warunki współpracy.

3) Przedłużenie dostępu do mobilności tych samych pojazdów w ramach nowej umowy czy/i umowy stanowiącej przedłużenie umowy poprzednio obowiązującej między stronami.

Wydaje się, że docelowo dostawcy taboru na rynek pierwotny zmienią również zasady działania rynku wtórnego. Już obecnie są oni na nim niezmiernie aktywni, powoli rugując z niego niezależnych pośredników, jak Alga czy Klein Trucks, oraz sprzedaż przez dotychczasowych właścicieli. W tym drugim przypadku zagadnienie odnosi się głównie do taboru odbieranego w rozliczeniu przy zakupie nowych egzemplarzy. Są to przeważnie transakcje typu buy-back, gdy dostawca nowego taboru odbiera od przewoźnika tabor sprzedany mu uprzednio przez siebie bądź sprzedany przez jednego z najważniejszych konkurentów. Wobec tego należy oczekiwać, że w przyszłości idea dysponowania oraz posiadania wraz z zasadą nie zakupu, a płatności za dostęp do mobilności niemal w pełni zostaną przez dostawców pojazdów przeniesione z rynku pierwotnego na wtórny. W efekcie nawet na rynku wtórnym tabor będzie de facto wyłącznie wynajmowany. Tym samym dostawcy taboru przejmą pełną kontrolę nad nim i będą jego właścicielami od momentu sprzedaży do momentu skierowania do zezłomowania, czyli przez cały okres jego rynkowego życia. Dzięki temu, w pełni kontrolując oba rynki, pierwotny i wtórny, będą w stanie odpowiednio nimi zarządzać. Jest to niezwykle istotne w okresie dekoniunktury na usługi przewozowe, gdy podmiotom leasingowym zwracany jest nieraz tabor od przewoźników mających problemy, a potem leasingowany ponownie za mniejszą opłatę. Wówczas taki ponowny leasing egzemplarzy prawie nowych - dwu-, trzyletnich - w znacznym stopniu negatywnie odbija się na leasingu egzemplarzy fabrycznie nowych, ograniczając produkcję i dostawy. W nowym modelu producent przejmujący pojazdy z wynajmu sam decyduje, co z nimi zrobić: czy przetrzymać i dopiero potem skierować do wynajmu, by nie zaburzać dostaw nowego taboru, czy też mimo wszystko od razu ponownie skierować do wynajmu, ale jedynie na satysfakcjonujących warunkach, mając możliwość uzyskania zadowalającej wysokości rat.

Najszybciej nowe trendy, jeśli chodzi o tabor, pojawiają się sektorze przewozów dalekodystansowych, międzynarodowych. Przemawia za tym kilka zasadniczych, ściśle powiązanych ze sobą czynników. Przede wszystkim pod względem budowy jest to tabor najbardziej ujednolicony. W tym przypadku nie ma znacznej indywidualizacji doboru komponentów kluczowych i dodatkowych, niezwykle 
charakterystycznej dla odmian specjalizowanych i szczególnie specjalistycznych. W związku z tym egzemplarze zwrócone przez jednego użytkownika podmiotowi wynajmującemu lub leasingującemu bez większych problemów i dodatkowych kosztów mogą być przekazane innemu użytkownikowi do eksploatacji. Pojazdy takie mogą więc trafić przede wszystkim do flot wynajmujących je w ramach usługi dostępu do mobilności, gdyż - jak wskazano - nie wystąpią większe koszty i problemy, gdy będą przekazywane następnemu eksploatującemu.

Zmiany te będą przyczyną nowych zjawisk po stronie przewoźnika. Po pierwsze, nie będzie on posiadał taboru na własność, tylko będzie uzyskiwał do niego dostęp na określonych warunkach i na określony czas na podstawie umowy łączącej cechy obecnych umów leasingu i najmu, ewentualnie samego wynajmu. Może się oczywiście pojawić nowy rodzaj umowy. Po drugie, będzie się musiał zgodzić na usieciowienie, a tym samym na permanentną kontrolę oraz nadzór ze strony innego podmiotu nad użytkowanym przez siebie taborem i wszelkimi operacjami przewozowymi wykonywanymi za jego pomocą. Bez takiej zgody nie uzyska dostępu do mobilności, innymi słowy nie będzie mógł w ogóle eksploatować środków transportu. Po trzecie, pełną obsługę tych pojazdów w okresie obowiązywania umowy na dostęp do mobilności przejmą ich dostawcy. W efekcie w tym czasie jedynie oni będą odpowiadać za zapewnienie mobilności taboru. Jeśli mobilność nie zostanie zapewniona w określonym czasie czy/i na określonym poziomie gotowości technicznej, dostawca może być zobowiązany wypłacić przewoźnikowi odszkodowanie. Tym samym przewoźnik poza opłatami za dostęp do mobilności pokryje część kosztów stałych - wybrane opłaty i wydatki na pensje kierowców, jeśli pracują u niego na etacie, oraz koszty zmienne, jak koszty paliwa, AdBlue i opłaty drogowe za dostęp do infrastruktury: np. za przejazd tunelami albo niemiecki Maut czy nasz ViaToll. A ponieważ w tym modelu współpracy to dostawca taboru bądź afiliowana przez niego instytucja finansująca są właścicielami pojazdów, to oni zapłacą m.in. podatek drogowy. Niemniej jego koszty i tak ostatecznie pokryje przewoźnik w racie ustalonej opłaty comiesięcznej.

Wszystkie te zmiany będą się bezpośrednio wiązać z koniecznością zmiany podejścia przewoźników do prowadzenia biznesu, relacji z partnerami oraz przechodzenia od posiadania do dysponowania.

\section{Podsumowanie}

Procesy zachodzące na europejskim rynku dostaw taboru samochodowego do przewozów towarowych są niezaprzeczalnie następstwem tzw. czwartej rewolucji przemysłowej, oznaczającej przechodzenie gospodarek krajów wysoko rozwiniętych do poziomu określanego jako 4.0. Procesy te spowodują wiele istotnych zmian w przypadku wszystkich podmiotów związanych z rynkiem samochodowych przewozów towarowych - dostawców taboru, samych przewoźników oraz 
zlecających usługi. Zmiany te są obecnie wdrażane przez dostawców taboru oraz zleceniodawców, co nie pozostaje bez wpływu na przewoźników. To właśnie ich czeka najwięcej zmian w obszarach technicznym, organizacyjnym oraz mentalnym. Przede wszystkim w wyniku tej głębokiej transformacji będą musieli się zgodzić na usieciowienie, które już jest im w pewien sposób narzucane, stając się niezbędnym elementem, a nie tylko pewnym dodatkiem. Tym samym przewoźnicy będą musieli się zgodzić na wypływ ze swojej firmy danych, których wypływu nie zawsze mogą sobie życzyć. $Z$ drugiej strony będą mogli jednak rezygnować z posiadania własnego zaplecza obsługowo-naprawczego, gdyż stanie się ono w znacznym stopniu czy nawet całkowicie zbędne. Następować będzie w takim razie odchodzenie od potrzeby posiadania takiego zaplecza, a przynajmniej konieczne stanie się jego ograniczenie.

Schemat i zasady funkcjonowania rynku w pierwszym rzędzie będą dotyczyć rynku pierwotnego oraz dużych przewoźników, tzw. flotowych i przewoźników mniejszych, wykonujących zadania na rzecz dużych przewoźników, spedytorów, operatorów logistycznych albo liczących się zleceniodawców pierwotnych. Zleceniodawcy ci bowiem ze swojej strony także wymagają dzisiaj usieciowienia.

Docelowo dojdzie więc do powiązania - $\mathrm{w}$ ramach zintegrowanych otwartych platform informatycznych - usieciowienia dostawców taboru z usieciowieniem zlecających usługi przewozowe. W te sieci włączeni też zostaną przewoźnicy, a usieciowienie zapewni bardzo dużą transparentność operacji. Jednocześnie wyraźne będzie dążenie do wdrażania jednolitych platform sieciowych obejmujących rozproszone dotychczas systemy sieciowe, po części funkcjonujące niezależnie. Kwestia dotyczy połączenia w jedną zintegrowaną platformę wszystkich systemów pochodzących z różnych źródeł, od różnych podmiotów - dostawców taboru, zleceniodawców, przewoźników - i stworzenia na tej bazie homogenicznej platformy sieciowej o eklektycznym i holistycznym charakterze.

Usieciowienie stanie się więc pierwszym, przed autonomizacją prowadzenia oraz pełną elektryfikacją, szerokim upowszechnieniem proekologicznych napędów w pełni elektrycznych, namacalnym dowodem przechodzenia do Transportu 4.0.

\section{Bibliografia}

Baur C., Wee D. (2015), Manufacturing's next act, McKinsey \& Co., www.mckinsey.com/business-functions/operations/our-insights/manufacturings-nextact (data dostępu 05.11.2017).

Bernsmann A., Clausen U., Heinrichmeyer H., Stütz S. (2016), ZF FUTURE STUDY 2016, Last Mile Logistics, Fraunhofer-Institut für Materialfluss und Logistik IM. Brach J. (2017), Mobilność 4.0, Pojazd Użytkowy 4.0 oraz Transport 4.0 - kwestie definicyjne i praktyczne, materiały konferencyjne: XX Konferencja Naukowa TranSopot 2017, Wyzwania Rozwoju Transportu w XXI wieku, Sopot, w druku. 
Continental, materiały wewnętrzne, 2017.

DAF, materiały wewnętrzne, 2017.

The Future is Smart - Image Processing is an Important Component of Industry 4.0, Basler AG, www.baslerweb.com/en/vision-campus/markets-and-applications/image-processing-industry-4-0/ (data dostępu 05.11.2017).

Heinrichmeyer H. (2017), Structural Planning of Networks for Transport Service Providers, Fraunhofer Institute for Experimantal Software Engineering, www.iml.fraunhofer.de/en/fields_of_activity/transport_logistics/topics_ transport_logistics/networkplanning.html (data dostępu 05.11.2017).

Hülsmann T. (2015), Logistics 4.0 and the Internet of Things, materiały pokonferencyjne: Platforms for connected Factories of the Future, http://ec.europa. eu/information society/newsroom/image/document/2015-44/8 huelsmann_11945.pdf (data dostępu 05.11.2017).

Idea Bank, Happy Miles. Pierwszy leasing liczony kilometrami!, www.ideabank. pl/leasing-na-kilometry-happy-miles\#miles3 (data dostępu 05.11.2017).

Jeschke S. (2016), Quo Vadis Logistik 4.0. Changes and Future Trends in Transportation and Logistics, materiały pokonferencyjne: Transporeon Networking Event, Wolkenburg/Köln, www.ima-zlw-ifu.rwth-aachen.de/fileadmin/ user_upload/INSTITUTSCLUSTER/Publikation_Medien/Vortraege/download//Quo vadis Logistik4.0 17March2016.pdf (data dostępu 05.11.2017).

Jeschke S., Haberstroh M., Meisen T. (2014), Mobility 4.0: Distributed Intelligence for Future Transportation, materiały pokonferencyjne: Zukunft im Transportverkehr, Daimler AG, Berlin, www.ima-zlw-ifu.rwth-aachen.de/ fileadmin/user_upload/INSTITUTSCLUSTER/Publikation_Medien/Vortraege/download//Daimler 3July2014.pdf (data dostępu 05.11.2017).

Kagermann H., Wahlster W., Helbig J. (2013), Recommendations for implementing the strategic initiative INDUSTRIE 4.0, acatech - National Academy of Science and Engineering, www.acatech.de/fileadmin/user_upload/Baumstruktur_nach_Website/Acatech/root/de/Material_fuer_Sonderseiten/Industrie_4.0/ Final report Industrie 4.0 accessible.pdf (data dostępu 05.11.2017).

Kupczyk K. (2016), Zmiana modeli biznesowych na rynku medialnym w warunkach jego ucyfrowienia [w:] A. Kuźmińska-Haberla, K. Kupczyk (red.), Ekonomia i międzynarodowe stosunki gospodarcze, Seria Debiuty Studenckie, UE Wrocław, Wrocław.

Löffler M., Tschiesner A. (2013), The Internet of Things and the future of manufacturing, McKinsey \& Co., www.mckinsey.com/business-functions/digitalmckinsey/our-insights/the-internet-of-things-and-the-future-of-manufacturing (data dostępu 05.11.2017).

MacDugall W. (2014), INDUSTRIE 4.0. Smart Manufacturing for the Future, Germany Trade \& Invest, www.gtai.de/GTAI/Content/EN/Invest/_SharedDocs/Downloads/GTAI/Brochures/Industries/industrie4.0-smart-manufacturing-for-the-future-en.pdf (data dostępu 05.11.2017). 
Ruoff D. (2016), Industrie 4.0 - mit neuen Technologien zu innovativen Geschäftsmodellen [w:] M. Krupp, P. Richard, F. Waibel (red.), Fallstudien Der Schwäbischen Logistikwirtschaft, Hochschule Augsburg, University of Applied Science, Augsburg.

Trapp M. (2017), Industry 4.0. Everyone is talking about Industry 4.0 - but what does this actually mean?, Fraunhofer Institute for Experimantal Software Engineering, www.iese.fraunhofer.de/en/innovation_trends/industrie $40 . \mathrm{html}$ (data dostępu 05.11.2017).

Weiss Ch. (2016), Wirtschaftskriminalität - Steigendes Angriffsrisiko durch Realisierung von Industrie 4.0 [w:] M. Krupp, P. Richard, F. Waibel (red.), Fallstudien Der Schwäbischen Logistikwirtschaft, Hochschule Augsburg, University of Applied Science, Augsburg.

\section{Streszczenie}

W artykule opisano nowe tendencje, które można zaobserwować ostatnio na europejskim rynku pojazdów użytkowych do przewozów towarowych. Procesy te są głównie spowodowane tzw. czwartą rewolucją przemysłową, która doprowadziła do powstania Przemysłu 4.0 oraz związanych z nim: Logistyki 4.0 i Transportu 4.0. Zmiany te w znacznym stopniu wpływają na działalność - funkcjonowanie wszystkich stron włączonych w tę część biznesu - dostawców taboru, przewoźników, zleceniodawców.

Słowa kluczowe: Transport 4.0, dostawca i odbiorca taboru

\section{Summary}

The contemporary changes on the European market of supply of freight transport road vehicles

In this paper there are described new tendencies which - in the recent times - have been taking place on the European market of commercial vehicles for freight transport. These processes are mainly caused by the forth industrial revolution which drives to creation of Industry 4.0 and connected with it Logistics 4.0, Transport 4.0 and Mobility 4.0. These changes have a strong influence on the activities of all parties involved in that part of the business - fleet suppliers, hauliers, customers.

Keywords: Transport 4.0, fleet supplier and buyer

JEL: R40 